\title{
Shock of Paradigms on the Instrumentation of Curved Root Canals
}

\author{
Jesus Djalma PÉCORA \\ Alexandre CAPELLI \\ Department of Restorative Dentistry, Faculty of Dentistry of Ribeirão Preto (FORP), \\ University of São Paulo, Ribeirão Preto, SP, Brazil
}

\begin{abstract}
This paper makes a practical analysis about the paradigm on the instrumentation of curved root canals. In Endodontics, a paradigm has been created. Theories and techniques for instrumentation of curved root canals state that the use of a \#25 file in the apical portion fulfills all the requirements for cleaning and shaping of the root canal system. Every scientific theory or paradigm should be continuously opened to modifications or refutation. The existence of extremely flexible instruments fabricated from metal alloys, methods for accurate determination of the real anatomic diameter and achievement of optimal shaping and cleaning of the apical portion created new theories and a new paradigm on the instrumentation of curved root canals. Therefore, this new insight will gradually modify the mentality of researchers and clinicians, but will still be open to further investigations and theories.
\end{abstract}

Key Words: paradigm, root canal instrumentation, curved root canals.

\section{INTRODUCTION}

Before we begin demonstrating the shock of paradigms on the instrumentation of curved root canals, it is relevant to make some important considerations concerning the word paradigm.

Every point of view is supported by certain premises regarding the nature of reality. When this fact is accepted, the premises work as an hypothesis; when it is disregarded, the premises work as a belief. The assemblies of hypotheses generate the theories and the assemblies of theories create the paradigms (1). Therefore, a paradigm is a sort of general theory of objectives, capable of either comprising most of the phenomena known in its field or providing them a context.

It may be assumed that every scientific theory or paradigm is continuously opened to modifications or refutation. Nevertheless, successful theories may invariably tend to be considered as correct. They turn into normative paradigms, become unquestionable concepts and begin to determine the right way to act, do and think.
It is mandatory to be open-minded to question the paradigms that involve our profession, because whenever a paradigm acquires an extraordinary impact over those who adhere to it, it may become an indubitable belief. In the majority of the times, such adherence may create a strong connection, which leads both clinicians and researchers to admit solely their own theory, for it seems evident to them that there is no other way to be. It constitutes the so-called settlement of the paradigm.

In Endodontics, a paradigm has been created. Theories and techniques for instrumentation of curved root canals state that the use of a \#25 file in the apical portion fulfills all the requisites for cleaning and shaping of the root canal system. The theories emphasize that, beyond this numbering (\#25), failures such as deviations, perforations, zipp, etc, may occur frequently (2-5).

Therefore, one created the paradigm of the instrumentation of curved root canals, stating that the apical portion must be instrumented up to a \#25 file. As regards, manual instrumentation, this approach is partly correct, considering that root canal instrumentation used to be performed with stainless steel instruments

Correspondence: Prof. Dr. Jesus D. Pécora, Departamento de Odontologia Restauradora, Faculdade de Odontologia de Ribeirão Preto, USP, Av. do Café, S/N, 14040-904 Ribeirão Preto, SP, Brasil. Tel: +55-16-3602-3982. Fax: +55-16-3633-0999. e-mail: pecora@forp.usp.br 
that did not present flexibility beyond this numbering (\#25). However, over the twentieth century, the findings of optical and scanning electron microscopic studies showed that, indeed, cleaning of curved root canals was defective. To date, none of the techniques available is able to yield an accurate cleaning of the apical portion of curved root canals (6-19).

Despite the evidence provided by the outcomes of scientific investigations, the paradigm remained emphatic as regards the method for preparation of curved root canals, that is instrumentation of the apical portion up to the \#25 file.

Nevertheless, anatomy studies revealed that the anatomic diameter of the apical portion of the mesiobuccal canals of maxillary molars corresponds to that of a \#25 or \#30 (13) file. So, it may be assumed that when a \#25 file is last used for instrumentation, root canal cleaning is not efficient. As a result, if the cleaning of the canals is not appropriate, especially in teeth with necrotic pulps with or without lesion, the use of too much interappointment endodontic dressing is required.

Although there is strong evidence of lack of cleaning and lack of preparation of the apical portion, the paradigm persists even in spite of the outstanding technological advance because all the evolution experienced has been adapted to the existing paradigm.

This paradigm remained successful along the whole 20th century; however, it began to be modified in the 21th century by the following approaches:

a) The existence of extremely flexible manual and rotary instruments fabricated from nickel-titanium (NiTi) alloys, mainly those of .02 taper. As far as the operator is familiar with the technique of instrumentation and have the skills to perform it, the apical portion of curved root canals may be prepared using $\mathrm{NiTi} \# 40$, \#45 or \#50 files (.02 taper) safely, with no risk of causing deviations, perforations or zipping,

b) The real determination of the apical anatomic diameter or the real determination of the first initial instrument. For such purpose, the canals must be previously enlarged at the middle and cervical thirds with modern instruments (Orifice Shaper, Flare, EndoFlare, Coronal Shaper, LA Axxess).

c) Achievement of optimal shaping and cleaning of the apical portion, obtained by effective microsurgery of the root canals using three or four instruments above the one that determined the real anatomic diameter. Therefore, in this region, dentin will be removed at approximately 150 to 200 microns.

This change of attitude, based on the aforementioned features, led these new hypotheses to create other theories and a new paradigm on the instrumentation of curved root canals. So, this new insight will gradually modify the mentality of researchers and clinicians, but will still be open to further investigations and new theories.

\section{DISCUSSION}

The introduction of a new paradigm may face extraordinary difficulties because it creates a shock of paradigms. Whenever a shock of paradigms occurs, the antagonisms and the faulty communication among the researchers are commonly observed.

There are those who remain locked to the past, to the ancient paradigm of instrumentation of curved root canals, not taking into account that it was based on the use of non-flexible stainless steel files.

Moreover, the corporations that produce rotary instruments have not become aware of the new paradigm, according to which the instrumentation of curved root canals may be carried out with nickel-titanium instruments. They insist on divulgating these new technologies as to be utilized according to the principles of the ancient paradigm. Such corporations insist on advising the use of these instruments based on the crown-down technique transposed from manual instrumentation. This is an error to be avoided because the proposed instrumentation makes the tip of the instrument to be engaged during the preparation, thereby leading to instrument breakage as a consequence of torsional load. In order to overcome the problem of fracturing of rotary instruments it is necessary to change the idea of the crown-down instrumentation adapted from manual instrumentation. A new concept of rotary instrumentation has been proposed (Free Tip preparation), according to which, the tip of the instrument works freely inside the canal most of the time, acting as a guide to the instrument, thereby minimizing the possibility of fracture by torsion significantly (20).

Another mistake made by the manufacturers is to fabricate instruments in which the taper of the \#25 files is increased, but the tip of the file is maintained. Therefore, although the canals instrumented using \#25 taper .04 or 06 files are well shaped, the apical portion is underprepared and so it is not clean because the 
contaminated dentin is not appropriately removed. In addition, it is known that the greater the taper of a $\mathrm{NiTi}$ instrument, the lesser its flexibility. Thefore, with respect to curved root canals, it is important that the apical third be prepared with .02 taper files, thus preventing failures and providing a more accurate cleaning. A NiTi \#45 taper .02 file is flexible enough to be utilized in curved areas. Greater flexibility would be achieved if parallel instruments (taper 00) were developed in the future.

Inview of this, the instrumentation (microsurgery) of the apical portion of curved root canals must be accomplished with .02 taper files because this region may be prepared with three, four or five instruments beyond the real anatomic diameter. However, the real anatomic diameter must be first determined.

The development of this new paradigm will be clearly demonstrable by further studies. An open-minded approach is essential for progress and Endodontics is now leaving behind the art stage (handicraft) to reach the technological stage, in which the general practitioner will be able to perform the treatment of curved canals successfully, as long as he/she is familiar with the technique of instrumentation.

\section{RESUMO}

Este artigo faz uma análise crítica do paradigma da instrumentação de canais radiculares curvos. Na Endodontia, criou-se um paradigma onde teorias e técnicas de instrumentação de canais radiculares curvos estabelecem que a utilização de uma lima \#25 na região apical preenche todos os requisitos para a limpeza e modelagem dos canais. Toda teoria ou paradigma científico deve estar continuamente aberto a modificações ou refutação. A utilização de instrumentos fabricados com ligas metálicas mais flexíveis, formas de determinação precisa do real diâmetro anatômico e a obtenção de uma limpeza eficiente da porção apical criaram teorias e um novo paradigma de instrumentação de canais radiculares curvos. Assim, essa nova visão irá modificar a mentalidade dos pesquisadores e clínicos, que devem estar abertos a novas investigações e novas teorias.

\section{REFERENCES}

1. Walsh RN, Vaughan F. Beyond ego: transpersonal dimensions in Psychology. Los Angeles: JP Tarcher; 1980.

2. Abou-Rass M, Frank AL, Glick DH. The anticurvature filing method to prepare the curve root canal. J Am Dent Assoc 1980;101:792-794.

3. Al-Omari MAO, Dummer PMH. Canal blockage and debris extrusion with eight preparation techniques. J Endod 1995;21: 57-61.

4. Hülsmann M, Schäfers F. A comparative study of root canal preparation with HERO 642 and Quantec SC rotary instruments. Int Endod J 2001;34:538-546.

5. Barbizam JV, Fariniuk LF, Marchesan MA, Pécora JD, SousaNeto MD. Efectiveness of manual and rotary instrumentation techniques for cleaning flattened root canals. J Endod 2002;28:365-366.

6. Bolanos OR, Jensen JR. Scanning electron microscope comparison of the efficacy of various methods or root canal preparation. J Endod 1980;6:815-822.

7. West JD, Roane JB, Goerig AC. Cleaning and shaping the root canal system. In: Pathways of the Pulps. Cohen S, Burns RC (Editors). 6th ed. St. Louis: Mosby Year Book; 1994. p. 179218.

8. Wu MK, Wesselink PR. Efficacy of three techniques in cleaning the apical portion of curved root canals. Oral Surg, Oral Med, Oral Pathol, Oral Radiol Endod 1995;79:492-496.

9. Wu MK, Roris A, Barkis D, Wesselink PR. Prevalence and extent of long oval shape of canals in the apical third. Oral Surg, Oral Med, Oral Pathol, Oral Radiol Endod 2000;89: 739-743.

10. Hülsmann M, Schade M, Schäfers F. A comparative study of root canal preparation with HERO 642 and Quanted SC rotary Ni-Ti instruments. Int Endod J 2001;34:538-546.

11. Wu MK, Wesselink PR. A primary observation on the preparation and obturation of oval canals. Int Endod J 2001;34:137-141.

12. Wu MK, Kastakova A, Wesselink PR. Quality of cold and warm gutta-percha fillings in oval canals in mandibular premolars. Int Endod J 2001;34:485-491.

13. Vanni JR, R Santos, Limongi O, Guerisoli DMZ, Capelli A, Pecora JD. Influence of cervical preflaring on determination of apical file size in maxillary molars: SEM analysis. Braz Dent J 2005;16:181-186.

14. Gambarini G, Laszkiewicz J. A scanning electron microscopic study of debris and smear layer remaining following use of GT rotary instruments. Int Endod J 2002;35:422-427.

15. Grandini S, Balleri P, Ferrari M. Evaluation of Glyde File Prep in combination with sodium hypochlorite as a root canal irrigant. J Endod 2002;28:300-303.

16. Guerisoli DMZ, Marchesan MA, Walmsley AD, Pecora JD. Evaluation of smear layer removal by EDTAC and sodium hypochlorite with ultrasonic agitation. Int Endod $\mathrm{J}$ 2002;35:418-421.

17. Pécora JD, Capelli A, Seixas FH, Maechesan MA, Guerisoli DMZ. Rotary Biomechanics: Reality or Future? http:// www.forp.usp.br/restauradora/rotatorios/free/ rotary_biomechanics.html.

18. Rödig T, Hülsmann M, Mühge M, Schäfers F. Quality of preparation of oval distal root canals in mandibular molars using nickel-titanium instruments. Int Endod J 2002;35:919928.

19. Hülsmann M, Gressmann G, Schäfers F. A comparative study of root canal preparation using FlexMaster and HERO 642 rotary Ni-Ti instruments. Int Endod J 2003;36:358-366.

20. Schäfers F, Schlingemann R. Efficiency of rotary nickeltitanium K3 instruments compared with stainless steel hand K-Flexofile. Part. 2. Cleaning effectiveness and shaping ability in severely curved canals of extracted teeth. Int Endod J 2003;36:208-217.

Accepted March 18, 2005 